\title{
Beyond limits - the pitfalls of global gene drives for environmental risk assessment in the European Union
}

\author{
Marion Dolezel', Christoph Lüthi², Helmut Gaugitsch' \\ I Environment Agency Austria, Spittelauer Laende 5, 1090, Vienna, Austria 2 Federal Office for the Envi- \\ ronment FOEN, Worblentalstrasse 68, 3063, Ittigen, Switzerland \\ Corresponding author: Marion Dolezel (marion.dolezel@umweltbundesamt.at)
}

Academic editor: J. Settele | Received 11 December 2019 | Accepted 2 March 2020 | Published 4 May 2020

Citation: Dolezel M, Lüthi C, Gaugitsch H (2020) Beyond limits - the pitfalls of global gene drives for environmental risk assessment in the European Union. BioRisk 15: 1-29. https://doi.org/10.3897/biorisk.15.49297

\begin{abstract}
Gene drive organisms (GDOs) have been suggested as approaches to combat some of the most pressing environmental and public health issues. No such organisms have so far been released into the environment, but it remains unclear whether the relevant regulatory provisions will be fit for purpose to cover their potential environmental, human and animal health risks if environmental releases of GDOs are envisaged. We evaluate the novel features of GDOs and outline the resulting challenges for the environmental risk assessment. These are related to the definition of the receiving environment, the use of the comparative approach, the definition of potential harm, the stepwise testing approach, the assessment of long-term and large-scale risks at population and ecosystem level and the post-release monitoring of adverse effects. Fundamental adaptations as well as the development of adequate risk assessment methodologies are needed in order to enable an operational risk assessment for globally spreading GDOs before these organisms are released into environments in the EU.
\end{abstract}

\section{Keywords}

environmental risk assessment, European Union, gene drive, genetically modified organism, GMO

\section{Introduction}

New genetic engineering tools for manipulating genetic material in plants, animals and microorganisms have received considerable attention over the last years. Many of these techniques are novel and based on recent developments in molecular biology. Some of these techniques can be used to modify genomes of organisms in a way that increases

Copyright Marion Dolezel et al. This is an open access article distributed under the terms of the Creative Commons Attribution License (CC BY 4.0), which permits unrestricted use, distribution, and reproduction in any medium, provided the original author and source are credited.. 
the inheritance of particular genes during sexual reproduction. The higher prevalence of these genes in the offspring leads to increased spread of the genes in the whole population - a mechanism termed "gene drive". This enhancement of the ability of a genetic element to pass from the parent to its offspring through sexual reproduction is a basic feature of all gene drive systems (NAS 2016). Different mechanisms have so far been used to achieve gene drive in different target populations, such as transposable elements (Marshall and Akbari 2016), meiotic drives (Lindholm et al. 2016), or combinations of genes coding for toxins and antidotes such as MEDEA or underdominance systems (Akbari et al. 2013, 2014). Also intracellular bacteria (e.g. Wolbachia) have been used to spread genes in specific target populations (Sinkins and Gould 2006; Iturbe-Ormaetxe et al. 2011). In recent years, nuclease-based techniques for genetic engineering have been developed for the specific design of synthetic (in contrast to natural) gene drive approaches. Nucleases are enzymes that typically induce doublestrand breaks at specific target sites in the genomic DNA. Homing endonuclease genes (HEG) express an endonuclease, which can be designed to cleave specific target sequences in the host genome, followed by repair using the HEG-bearing chromosome as a template (Burt 2003; Marshall and Akbari 2016). "Homing" is referred to as the copying of the HEG into the target recognition site of the wild-type chromosome by homology-directed repair (Marshall and Akbari 2016). As a result, a heterozygote is converted into a homozygote with both chromosomes containing a copy of the homing endonuclease gene (Burt 2003).

With the discovery of CRISPR/Cas (Clustered Regularly Interspaced Short Palindromic Repeats/CRISPR associated protein), the development of gene drive approaches was simplified and accelerated, as many of the targeting and stability problems observed in other nuclease-based genetic engineering techniques could be overcome (Esvelt et al. 2014; Min et al. 2018). Guide RNAs (gRNA) are attached to the nuclease, directing the nuclease-RNA complex to the genomic DNA target sequence, which is complementary to the sequence of the gRNA. By using synthetic gRNAs, one or several target sequences can be specifically addressed. The gene drive is achieved as with other nuclease-based systems, e.g. by providing a repair template for homologous recombination and subsequent incorporation into both chromosomes. The newly incorporated sequences serve as a constant source for further conversion of heterozygous to homozygous alleles. In recent years, a range of proof of concept studies have shown the feasibility of synthetic CRISPR-based gene drives in different organisms, such as yeast (DiCarlo et al. 2015a, b), the fruit fly Drosophila melanogaster (Gantz and Bier 2015), mosquitoes (Gantz et al. 2015; Hammond et al. 2016) and partly also mammals (Grunwald et al. 2019).

Several potential applications for gene drive systems in three main fields have been suggested, i.e. in public health (e.g. vector control of human pathogens), in agriculture (e.g. control of weeds or pests), and in environmental protection and nature conservation (e.g. the control of noxious non-native species) (Esvelt et al. 2014; NAS 2016; AAS 2017). The latest comprehensive overview of applications and their current status can be found in CSS, ENSSER \& VDW (2019). Strikingly, the potential of 
the gene drive approaches to be used as effective remedies for insect-borne diseases such as malaria or dengue by control of their vectors has fuelled the optimism regarding their public health benefits (NAS 2016; O'Brochta 2016; Hammond and Galizi 2018). Considerations to apply gene drives as a public health tool are mirrored by genetic approaches to combat malaria in sub-Sahara Africa. Using a phased development pathway, a research consortium intends to start with the release of genetically modified (GM) mosquitoes and plans to ultimately adopt a gene drive based approach to bias the sex ratio of Anopheles mosquito populations in order to drastically reduce the number of vectors (Target Malaria 2019). The alleged application of such a gene drive approach in sub-Sahara African countries raises the question whether the appropriate legal and regulatory conditions for the releases are existent in these countries. Moreover, responsibilities for the efficacy and sustainability of such health interventions are unclear, also considering potential environmental and health implications if the desirable outcome of the intervention is not reached. While most of the gene drive applications have so far only been envisioned, only a few actually are in the research and development stage (see overview in CSS, ENSSER \& VDW 2019).

Substantial differences in gene drive applications have been identified compared to conventional genetically modified organisms (GMOs) such as GM crops or GM insects, both with regard to the general strategy applied to cope with agricultural, public health or environmental issues and to the anticipated benefit (Simon et al. 2018). In addition, the potential environmental implications and adverse ecological outcomes for wild populations of species and ecosystems (e.g. Hayes et al. 2018) as well as challenges for the governance and the regulation of gene drive applications were emphasised (Oye et al. 2014; NAS 2016; AAS 2017; Callaway 2017b; Simon et al. 2018). Based on their potential for serious ecological and societal effects and the apparent gaps in the regulatory oversight and governance of gene drive applications, the release of gene drive organisms (GDOs) into the environment has been strongly opposed by some (Civil Society Working Group on Gene Drives 2016). In addition, increased transparency of scientific research projects and the involvement of the public and the civil society when implementing gene drive applications have been called for (Esvelt 2017). Others have emphasised the potential benefits of gene drive applications and have called for continued laboratory research and controlled field trials as well as novel governance forms (NAS 2016; Kofler et al. 2018; Hartley et al. 2019; Kuzma 2019).

Due to the novelty in the strategy and the predicted power of impact of gene drive applications, the assessment of their potential risks to the environment and human and animal health will be of high importance if these organisms are to be deliberately released into the environment. The potential of GDOs for unlimited spread throughout wild populations, once released, and the apparently inexhaustible possibilities of multiple and rapid modifications of the genome in a vast variety of organisms, including higher organisms such as vertebrates, pose specific challenges for the application of adequate risk assessment methodologies. The suitability and practicability of existing regulatory policies and risk assessment regimes when deploying GDOs have been discussed for the Australian (AAS 2017) and the US regulatory system as well as at 
international level (Oye et al. 2014). The Australian regulatory framework for GMOs foresees regulation of GDOs if these are created by the use of site-directed nucleases, such as CRISPR/Cas, although also other legislative provisions and acts may apply, depending on the specific case (AAS 2017). In the US, gene drives are currently regulated as veterinary medicines or toxins, if genetically modified DNA constructs affect the structure and function of an animal. It has been questioned whether this accounts for gene drives applications targeting invasive species or insects (Oye et al. 2014). For the European Union, an evaluation is still pending. The High Level Group of the European Commission`s Scientific Advice Mechanism highlighted risks in case GDOs were accidentally released, and noted that such risks may not be sufficiently covered by current regulatory frameworks (European Commission 2017).

In this article, we evaluate the novel features of gene drive approaches compared to conventional GMOs and outline the resulting challenges for the environmental risk assessment, which is an integral part of the EU's regulatory approval procedure. Although we mainly refer to CRISPR/Cas-based gene drive approaches, the analysis is also applicable for other types of GDOs, if these have the potential to spread globally. First, we briefly discuss regulatory provisions in the EU, such as those for GMOs, invasive alien species and biological control agents, with respect to their suitability to cover risks of global gene drive approaches. We outline the advantages and appropriateness of GMO regulation for GDOs in the European Union. We then address the major distinctive features of GDOs compared to GMOs without gene drive and highlight challenges with respect to the basic principles of environmental risk assessment for GMOs in the EU. For the evaluation of environmental risks, we refer to Directive 2001/18/EC (European Commission 2001) and its recent amendments (European Commission 2018a, 2018b) as well as relevant guidance documents issued by EFSA (e.g. EFSA 2010a, EFSA 2010b, EFSA 2013).

\section{Discussion}

\section{Regulation of GDOs in the EU}

Due to the versatility of gene drive applications regarding the underlying methodology applied and the targeted species, the decision which regulatory framework to apply might not be without ambiguity. Approaches to control pest species by the large-scale deployment of GM insects or GDOs may have similar environmental implications as biological control agents (NAS 2016). For example, Wolbachia-infected mosquitoes have been released into the environment with the aim to control dengue in Australia (Hoffmann et al. 2011). Although not being genetically modified, Wolbachia-infected mosquitoes have been mentioned as gene drive-like approaches (e.g. Macias et al. 2017; Leftwich et al. 2018), most likely due to the ability of the bacterial symbiont to invade and spread within insect host populations, thereby achieving a self-sustaining modification of the vector population. The mosquitoes were regarded neither as 
GMO, nor as biological control agent, and the release of the mosquitoes was regulated as a veterinary chemical product, albeit using the risk analysis framework for GMOs (De Barro et al. 2011).

In Europe, the introduction and deployment of invertebrate biological control agents is subject to national rules and regulatory provisions, if such are available. Individual EU Member States as well as Switzerland have introduced national legislation that differs in scope and risk assessment requirements (Hunt et al. 2007; Aebi and Schoenenberger 2016). Guidelines for information requirements for the import and the release of invertebrate biocontrol agents in Europe have been published by the International Organization for Biological Control of noxious animals and plants Commission (Bigler et al. 2005). These guidelines have been recommended as the official European standard (Hunt et al. 2007). The guidelines cover only invertebrate species and focus on insects, mites and nematodes. Although the guidelines refer to native and non-native organisms, it has been recommended to apply regulation only to exotic, non-native biological control agents (Hunt et al. 2007). The information requirements for environmental risks comprise the potential for dispersal and establishment, the host-range assessment, effects on plants, as well as direct and indirect nontarget effects. In addition, human health risks are addressed. Even fewer information requirements apply for native biological control agents. Hence, only basic information requirements would apply to the use of native invertebrate GDOs in the EU if these were regulated as invertebrate biocontrol agents. The assessment of environmental and human health risks of GDOs with the potential for global spread would be subject to individual national regulatory provisions.

In the European Union, Regulation 1143/2014 on Invasive Alien Species (IAS) provides for a set of measures to be taken across the EU for those IAS included on a list of IAS of Union concern. The Regulation refers to animals, plants, fungi and microorganisms. The measures relate not only to the detection, eradication and management of already present or even well-established invasive species, but also aim at preventing species of Union concern from entering the EU, intentionally or unintentionally. Based on a risk assessment process, the regulation intends to prevent the introduction and spread of IAS with the potential to establish a viable population, to spread and to have a significant adverse impact on biodiversity or the related ecosystem services, on human health or the economy (Regulation (EU) No 1143/2014, Art. 4). As this Regulation refers only to organisms outside their natural range, it would not cover native GDOs.

GMOs are subject to regulation under the provisions of Directive 2001/18/EC for the deliberate release of GMOs into the environment, requiring an environmental risk assessment (ERA), possibly risk management measures and an obligatory post-market monitoring (European Commission 2001). If techniques according to Annex I A, part 1, of Directive 2001/18/EC are used to genetically engineer a gene drive organism, this will be considered a GMO falling under the provisions of the Directive. This would be of relevance for currently proposed synthetic gene drive approaches because they have specific recombinant genetic elements inserted, i.e. elements necessary for the functionality of the drive, such as elements encoding the nuclease, the guide RNA and 
specific cargo genes, either by use of a vector system or by direct introduction into the target genome. Of particular relevance for the ERA is Annex II of Directive 2001/18/ $\mathrm{EC}$, which lays down the principles for the environmental risk assessment as well as the recent amendments of Annexes II and III of Directive 2001/18/EC (European Commission 2018a, b). In addition, the European Food Safety Authority (EFSA) issued guidance documents for the ERA of GM plants and animals (e.g. EFSA 2010a, b; EFSA 2013). Thereby, the European regulatory provisions for GMOs provide for the assessment of environmental and human health risks before an organism is released into the environment. In addition to a stringent pre-release environmental risk assessment, a post-release monitoring of adverse effects for human health and the environment is mandatory (European Commission 2001, Articles 4, 13). Such features do not exist to this extent in regulations of IAS or guidelines for the introduction of invertebrate biological control agents. Directive 2001/18/EC covers all types of organisms, i.e. "any biological entity capable of replication or of transferring genetic material' (Article 2), with no restrictions regarding their origin or taxonomy. In addition, the risk assessment requirements provide for an assessment of the novel traits on a case-by-case basis, considering the species targeted, the specific modification at the genomic and phenotypic level and the specific receiving environment into which the organism is intended to be released. This is particularly important since a range of molecular methodologies is currently available to enable gene drive in organisms (see e.g. Burt and Crisanti 2018). All of them have their specificities regarding the effectiveness of spread and spread dynamics (e.g. low threshold drives vs. high threshold drives) or the likelihood of developing resistance (e.g. Sinkins and Gould 2006, Burt and Crisanti 2018; Rode et al. 2019). The methodology used to achieve gene drive as well as the specific construction and assembly of the genetic elements used are important information requirements for the ERA of GMOs. For example, the type of promoter used will affect the genetic constitution of the adult organism and consequently adult fitness (de Jong 2017; Rode et al. 2019). In combination with the effect of the introduced cargo gene and the receiving environment, the success of the drive and any potential risks are likely to vary, if taking genotype-environment interactions into account (de Jong 2017). Additionally, off-target effects may occur depending on the design and specificity of the gRNA (Sander and Joung 2014; Rode et al. 2019). Finally, the type of organism used for gene drive applications will also influence the potential environmental risks. The inherent biological and ecological characteristics of the different target organisms can affect a molecular drive system in different ways, e.g. due to their genetic diversity, the prevalence of existing resistance alleles in wildtype populations, the presence of taxonomically related species, their spread, migration and mating behaviour, generation time or population structure. All these aspects affect the effectiveness of the gene drive as well as the potential risks for the environment. Consequently, only the regulatory provisions for GMOs in the EU provide for a case-by-case pre-release assessment of risks together with a post-release monitoring of adverse effects for any types of organisms (plants, animals, native or nonnative) considering the specific novel trait(s) and the receiving environment into which the GDO is intended for release. 


\section{Novel features of gene drives}

\section{Novel feature 1: Alteration of wild populations with novel traits instead of "famil- iar" crop species and traits}

A major difference between "classic" GMOs and GDOs is the intentional alteration of wild populations (e.g. mosquitoes) instead of domesticated and "familiar" crop species with limited ability to disperse. So far, GMOs were agricultural crop species with a "history of safe use" (EFSA 2010a). These GM crop species (e.g. GM maize) are highly domesticated, genetically uniform and well-studied (Bowman et al. 2003; Meyer and Purugganan 2013). Crop species are grown within agricultural fields that are managed by humans with respect to nutritional parameters and the ecological interactions with competitors, predators and pathogens. In contrast, the habitats of wild populations of plants or animals are characterised by variable resource availabilities and differing physical and biological conditions. Hence, the plasticity in genotype, phenotype, behaviour or ecological niche use can be extensive for wild populations. For example, Australian populations of the house mouse Mus domesticus exhibit differences in reproductive and behavioural patterns compared to house mouse populations from other continents (Singelton and Redhead 1990). As another example, two molecular forms of the mosquito Anopheles gambiae exhibit larval habitat segregation and different larval anti-predator responses (Gimonneau et al. 2010).

Genetically modified traits used so far with GM crops (insect resistance or herbicide tolerance) presumably have no or negligible selective advantage in the absence of selective pressure, i.e. the herbicide application or the attack of the pest species (EFSA 2011). Such traits are subject to natural selection pressure and genetic drift and are mostly considered to be lost from the population (Ellstrand et al. 2013). In contrast, the modified genes and traits in GDOs are novel, intending to change the vectorial or parasite capacity of the host species or the ecological behaviour of the candidate organism such as host seeking and feeding behaviour (Deredec et al. 2011). Moreover, the goal of gene drive applications is to introduce a permanent change in the ecosystem, either by introducing a phenotypic change or by drastically reducing or eradicating a local population or a species. This is a fundamental difference to GM crops for which each single generation of hybrid seed is genetically modified, released into and removed from the environment after a relatively short period.

\section{Novel feature 2: Intentional and potentially unlimited spread of synthetic genes in wild populations and natural ecosystems}

The specific gene drive mechanism deployed in GDOs will determine the potential for spread within target populations, but also to populations of sexually compatible organisms. So-called threshold-dependent drive systems require a certain release frequency of the GDOs in order to achieve spread in a target population (Marshall and Akbari 2018). If this threshold is not reached, e.g. in a non-target population of a 
sexually compatible species where only few individuals come into contact with the wild relative, further spread of the driving elements will not be effective (Marshall and Akbari 2018). So-called threshold-independent drive systems spread at very low initial frequencies into the target population until fixation of the introduced genetic change in the population is achieved, or until the gene drive has disappeared together with the population or species. Such low threshold drives can more easily migrate between populations. Modelling has shown that even small releases of first generation CRISPR/ Cas-based gene drive applications are likely to result in a global spread of GDOs (Noble et al. 2017).

In the EU, GM crops so far considered for environmental release were not intended to deliberately transfer GM traits to other species. Gene flow of GM traits from "classic" GMOs was therefore viewed as an unintended consequence of the release due to the intrinsic biology of the plant species used for genetic engineering. Similarly, the possibility of the GM plant to persist as a feral population (e.g. GM oilseed rape) or to invade (semi-)natural habitats was an unintended consequence of the GM crop release into those environments where the GM plant was able to spread and persist, or where wild relatives existed. Gene flow of synthetic genes from crop to wild plants may entail several adverse ecological impacts, such as depletion of the genetic diversity (of the targeted population), increased weediness or invasiveness of the GM plants or GM-wild hybrids, as well as the risk of extinction of wild species (Ellstrand 2003; Ellstrand et al. 2013). Recognising the potential for these adverse effects, certain countries explicitly consider the uncontrolled dispersal and spread of GMOs and their traits in the environment or to other organisms undesirable (e.g. in Switzerland, where this is regulated in the Swiss Gene Technology Act and the Swiss Release Ordinance). For the same reasons, the monitoring of spontaneous GM plant populations in the environment has been demanded (EAA 2011; Bühler et al. 2018). Consequently, the assessment of environmental risks of organisms that deliberately transfer synthetic genes and GM traits to the same or other species is an unprecedented case for GMO risk assessment in the EU.

\section{Novel feature 3: Possibility for long-term risks to populations and ecosystems}

The novelty of GDOs and their distinctiveness from "classic" GMOs is based on the novel mechanism of inheritance and the ability to genetically engineer a wide range of genes in many different types of organisms. An important and distinct feature of GDOs is their potential to introduce long-term, if not infinite, changes in populations as well as the large-scale, if not complete, spread of novel genetic and phenotypic traits through a target population due to the repeated genomic intervention in each subsequent generation. Due to this "lab in the field" approach (Simon et al. 2018), the potential adverse effects of GDOs are also likely to be novel compared to those of conventional GMOs. The specific novel molecular and phenotypic characteristics may also induce novel and application-specific causal pathways for environmental effects (Hayes et al. 2018). 
The evolutionary stability of this potentially "infinite" copying mechanism of the genomic drive cassette is subject to some debate due to the formation of resistant alleles at the target site. The development of resistance to the gene drive in target populations has been proposed for many gene drive approaches, although for some gene drive systems (e.g. HEGs) the occurrence of resistance is a greater concern than for others (Bull 2015; Marshall and Akbari 2018). Resistance has not only been theoretically explored in proof-of-concept studies (e.g. Gantz and Bier 2015; Gantz et al. 2015; Unckless et al. 2015; Hammond et al. 2016; Champer et al. 2017), but recently also shown in cage experiments with Anopheles gambiae (Callaway 2017a; Hammond et al. 2017). Several molecular mechanisms and approaches have been proposed to circumvent the development of resistance (Noble et al. 2017; Vella et al. 2017; Kyrou et al. 2018). For example, it has been shown that specific molecular mechanisms can guarantee the evolutionary stability of gene drives, e.g. by creating successive generations of cyclic gene drive elements, by blocking drive-resistant alleles or by targeting highly conserved sequences (Kyrou et al. 2018; Min et al. 2018). However, the reliability of the proposed mechanisms under environmental conditions is questionable. In addition, the use of multiple gRNAs in order to achieve multiple and simultaneous genomic interventions has also been proposed to maintain the evolutionary stability of the gene drive and overcome resistant allele formation (Noble et al. 2017; Marshall et al. 2017; Champer et al. 2018). Such multiplexed genetic engineering is already being applied in plant research and can result in unpredictable phenotypic outcomes (Eckerstorfer et al. 2019).

Resistance development in target populations may not be considered as an ecological risk per se, but can entail ecological risks as well as consequences for human health (e.g. Murphy et al. 2010; David et al. 2013). If resistance occurs and the functionality and effectiveness of the gene drive is no longer provided, the ultimate goal of the gene drive will not be achieved, with unknown epidemiological and ecological consequences. For example, not re-sensitizing already resistant weeds may result in delayed adverse agricultural and environmental consequences, if conventional management measures have been interrupted during the release of the GDOs. Similarly, suspending the control of human pathogen vector populations may have immediate and severe health implications (Bull 2017; Hayes et al. 2018).

Regarding long-term ecological impacts, novel mortality factors and selection pressures that are introduced into a population can have significant evolutionary consequences on target and non-target organisms. Experience from the introduction of nonnative biological control agents and from invasive alien species shows that ecological impacts can vary from negligible to significant and even devastating, depending on the species and the recipient ecosystem (Louda et al. 2003, see summary in Blackburn et al. 2014). In particular, gene drive applications aiming at suppression of the target population have the potential to change the ecological food web by inducing a loss of prey populations, thereby impacting predators and diminishing food sources for different trophic levels (David et al. 2013; NAS 2016). Depending on the specific role of the targeted species in the ecosystem, such ecological effects may affect prey species, predators, competitors or even complex ecological interactions, ecological func- 
tions and ecosystem services. The long-term changes in population densities of target populations may induce indirect and cascading effects on communities and ecosystems (David et al. 2013).

A consequence of the permanent suppression of pathogen-transmitting vector populations can also be the altered virulence of the pathogen (David et al. 2013). Modelling of evolutionary responses of transgenic dengue control options showed that the blocking of the disease transmission and of mosquito biting increased the risk of enhancing the virulence of the pathogen to humans (Medlock et al. 2009). The strong selection exerted on the pathogen may result in evolutionary adaptive processes by extending the host range of the pathogen to other species (Benedict et al. 2010; Bull 2015). Such a "vector switching" has been shown for other diseases transmitted by mosquitoes (David et al. 2013). Interactions between different pathogen strains within a host and transmitted between hosts may also affect their virulence (David et al. 2013). Such adaptive processes in the vector species can occur with respect to changes in the vector capacity, i.e. the suitability of a vector species to transmit the parasite or human pathogen. This may result in the regain of competency of the mosquito species for the target pathogen or the acquisition of new competencies for other pathogens. Hence, effects on related pathogens, their vectors and their control also need to be considered when deploying gene drive approaches that aim at the reduction of pathogen competence of mosquitoes (Benedict et al. 2010). Changes in the relative abundance of different vectors (e.g. different mosquito species or strains) due to the relief from competition can result in increases in population sizes of secondary vectors (other than the targeted) which may also result in increased target disease transmission or new disease transmission levels (David et al. 2013).

Last but not least, the introduction of a novel control practice may affect existing control measures of a noxious species or pathogen-transmitting vector species. In case of population alteration or replacement of vector species, conventional control strategies such as the application of insecticides could compromise the novel control method (Benedict et al. 2010; Murphy et al. 2010).

\section{Challenges of gene drives for the ERA in the European Union}

\section{Challenge 1: The receiving environment cannot be defined for GDOs with the ability to spread globally}

One fundamental principle for the ERA of GMOs is the case-by-case principle laid down in Directive 2001/18/EC (EFSA 2010a). This principle combines several factors that may affect the type and likelihood of adverse effects to occur, such as the type of GMO, the genetic modification, the intended use and, importantly, the receiving environment (EFSA 2010a). The receiving environments are defined as the environments into which the GM animal or GM plant will be released, the GMO, their effluents or parts of the plant or animal may spread or escape, actively or passively, and into which 
the transgene or recombinant DNA may spread (EFSA 2010a; EFSA 2013). The receiving environment is characterised by the accessible ecosystem or geographical zone of cultivation and the management systems into which the GMO will be embedded (EFSA 2010a; EFSA 2013).

The release of GM crops into the environment is locally restricted to specific production areas where the respective crop can only be grown if the specific climatic, agronomic and environmental conditions are appropriate. In contrast, spread of GDOs into populations beyond a spatially defined location is highly likely (e.g. in case of low threshold drives). For wild populations habitat heterogeneity is common, notably for arthropod pest species, which can either simultaneously or successively occupy diverse habitats and may have a range of host species, in particular if they are generalists and polyphagous. For example, the invasive pest Drosophila suzukii occupies a range of different crop and non-crop habitats, some of which serve as refuges (Santoiemma et al. 2018). Different races of the major pest species in maize, Ostrinia nubilalis, can exhibit different host-plant preferences, thereby feeding not only on maize in agricultural plots but also on other host plants like hop and mugwort in natural habitats which is also reflected by different molecular forms (Bourguet et al. 2000; Martel et al. 2003; Bethenod et al. 2005). Similarly, different molecular forms of the malaria-transmitting mosquito Anopheles gambiae exhibit larval habitat segregation (Gimonneau et al. 2010).

In a specific receiving environment, genotype-environment interactions play a crucial role, not only for the success of the gene drive application, but also concerning the potential risks for the environment. In order to achieve the successful spread of GDOs, the fitness costs involved with the gene drive construct for the target organisms are of high relevance, as they can affect the threshold which is necessary for successful spread and fixation (de Jong 2017). Such fitness costs are usually estimated by modelling but may differ from the predictions under realistic conditions. Novel fitness costs may occur under certain environmental conditions, possibly counteracting the intended gene drive (Iturbe-Ormaetxe et al. 2011). For example, molecular resistance to the gene drive mechanism can vary between organisms with different genetic backgrounds, which is relevant for target populations with high standing genetic diversity (Miles et al. 2017; Champer et al. 2017). Genotype-environment interactions have been shown to be important even for conventional GM crops as they can modulate the plants phenotypic and environmental performance (Zeller et al. 2010; Trtikova et al. 2015). Such interactions can also influence the phenotype of GM animals such as fish, with deriving ecological consequences (Devlin et al. 2004; Sundström et al. 2007). Genotypeenvironment interactions are therefore important aspects to be considered during ERA and require knowledge about the receiving environment(s) into which the GMO will be released. In ERA, testing the performance and environmental behaviour of a GMO in a specific receiving environment, typically done in field-testing, therefore serves to provide knowledge about the specific genotype-environment interactions of the GMO in question (EFSA 2010a). The establishment of relevant baseline data of the receiving environment before release of a GMO provides a reference framework against which potential environmental changes can be compared to after the release (EFSA 2010a). 
If, for wild plant or animal (meta)populations a range of genotype-environment interactions are possible, then the testing environments need to be spatially limited for the ERA.

It has been proposed to carry out field trials with GDOs intended for pathogenvector control in locations where no vectors are naturally present, as an instrument for ecological confinement of GDOs (Akbari et al. 2015; NAS 2016). However, such an approach can only be of limited value to inform the ERA, because it ignores that the functionality and the environmental implications of the respective gene drive application depend on the environmental specificities of the location of release.

\section{Challenge 2: The safety of a GDO cannot be established based on a comparative assessment}

The comparative safety assessment of the GMO with a non-modified organism is the starting point for the ERA of GM plants and animals (EFSA 2010a; EFSA 2013). For the assessment of GM crops, a conventional plant with a similar genetic background shall be used as a comparator in order to identify any differences and hazards, based on the "history of safe use" of conventional crops (EFSA 2010a). For GM animals, a comparison with wild populations of the same or closely related species has been proposed, taking into account that individuals are used which are derived from the location into which the GM animal is expected to be released and which exploit a similar ecological niche as the GM animal in accessible ecosystems (EFSA 2013). The use of non-GM surrogate animals with similar traits to those of the GM animal has also been recommended, in addition to the comparison of the management systems (EFSA 2013). At least for GM crops, the concept behind the comparative safety assessment is the assumption that conventionally cultivated plants are safe for consumers, animals and the environment (Constable et al. 2007).

Gene drive approaches generally target wild populations with no genetic uniformity, familiarity or history of safe use instead of domesticated animals or crops. If wild populations of the target species or closely related species in target environments serve as a baseline in order to assess any phenotypic and ecological differences to the GDO, then the reference framework for comparison must not only consider the organism as such but also include the environment in which the comparator thrives. Identified differences between the GDO and wild populations do therefore not necessarily indicate a hazard but may be due to the phenotypic and ecological plasticity of the target population. For wild populations of animals, it will be even more difficult than for GM crops to identify whether such differences are due to the novel GM trait or due to the range of behavioural and ecological characteristics present in the population. Although the comparative assessment certainly has an indicative value for a basic phenotypic characterisation and comparison of the GDO with the wild population from which it derives, it will have to be complemented with criteria for the relevance of observed differences. Ideally, these criteria should be available before an assessment of a specific GDO needs to be done. 
Consequently, an assessment of differences between GDOs and their wildtype comparators will be impractical for wild populations intended for a global gene drive. The availability of relevant baseline information regarding a range of biological and ecological parameters of both target and non-target populations in the envisaged receiving environment is a prerequisite in order to identify differences between the GDO and its comparators, to evaluate its relevance and to derive risk scenarios. However, this is only feasible if gene drive applications can be spatially restricted and confined to a specific environment. If such a local gene drive is envisaged, an assessment of the genetic, phenotypic, behavioural and ecological baseline data may be feasible, depending on the degree of population differentiation in the target species at the specific location. Logically, such a comparative assessment will be redundant for gene drive applications aiming at suppression and elimination of the target population where no viable offspring is available.

\section{Challenge 3: The environmental impact of gene flow of GDOs cannot be assessed with the current ERA}

The novelty of gene drive applications is the deliberate and intended transfer of modified genetic elements to one or several populations of the target species. Due to intraand interspecific gene flow, gene drive may also spread to populations other than the targeted. Depending on the aim of the gene drive approach, this may be considered as a beneficial effect of a particular gene drive based control strategy (David et al. 2013; Hayes et al. 2018). Interspecific gene flow and hybridization between the mosquito species Anopheles gambiae and other disease-transmitting vector species, such as $A$. arabiensis, has been shown (Besansky et al. 1997). In addition, intraspecific hybridization between different molecular or chromosomal forms of $A$. gambiae may also be relevant (Oliveira et al. 2008; David et al. 2013). The genetic heterogeneity and diversity of wild populations can be extensive, as has been recently shown for $A$. gambiae from 15 locations in Africa, demonstrating the potential for adaptive gene flow in these species across the entire continent (Miles et al. 2017).

A thorough knowledge of the occurrence of potentially compatible species, the population dynamics and genetics of non-target populations, including knowledge of reproductive or other isolating mechanisms between populations, is therefore highly relevant in order to estimate the risk of gene flow to non-target populations. The large knowledge gaps with regard to the phylogenetic relatedness and ability for hybridization in many wild species hampers the assessment of risks for gene drives that are able to spread beyond a certain meta-population.

Consequences of intra- as well as interspecific gene flow of GDOs can be decreased fitness, population declines and reduced phenotypic diversity and displacement of native species (David et al. 2013). Unpredicted fitness effects have been reported in offspring crop-wild hybrids of GM crops (Xia et al. 2016; Yang et al. 2017). The inclusion of the assessment of the offspring generations of the GDO and potential changes in fitness-related parameters of these will therefore need to inform the ERA with respect 
to unintended consequences due to different genetic backgrounds of target and nontarget populations.

Both, the ERA for GM crops and for GM animals provide the basis for an assessment of spread, persistence and invasiveness including gene flow (EFSA 2010a; EFSA 2013). In order to determine the relevance of an observed effect (e.g. increased persistence, fitness or changes in the population range of feral plants or wild compatible relatives), EFSA refers to a separate - yet unspecified - assessment to determine the environmental impact (EFSA 2010a). For GM animals, the environmental consequences and the potential harm due to gene flow and its resulting impacts on the receiving environments have to be determined during ERA (EFSA 2013). However, environmental harm has not yet been assessed or determined in ERA, even for "classic" GMOs. Specification of environmental harm due to spread, persistence or gene transfer by the application of GDOs could include: gene transfer to non-target organisms in target environments, e.g. mosquito species without disease transfer capacity, or spread and dispersal of GDO populations to non-target environments (e.g. natural habitats). Such spread into non-target habitats has been observed e.g. for non-native biocontrol agents (Louda et al. 2003).

\section{Challenge 4: Testing of GDOs in the field is hardly possible}

A major principle in the European GMO regulation is the step-by-step principle, also referred to as stepwise approach (EFSA 2010a). This principle refers to the gradual reduction of containment of a GMO and the gradual increase of the scale of release, including field-testing at the research stage in the ecosystems which could be affected by their use (European Commission 2001, recitals 24 and 25). Such a phased testing and release strategy has also been recommended for GM mosquitoes and GDOs, starting with laboratory tests, proceeding to cage testing before conducting confined and open field releases (WHO 2014; Hayes et al. 2018). Gradually decreasing the containment of a GMO by field-testing enables to build up specific knowledge of the GMO and its environmental behaviour. Thus, uncertainties about environmental risks can be reduced.

Already for laboratory experiments with GDOs, developers of gene drive applications have proposed extensive ecological, physical and molecular confinement methods in order to avoid escape of organisms from the lab (Akbari et al. 2015; RIVM 2016, 2018; NAS 2016). Notification procedures and monitoring of accidental releases of GDOs from the laboratory or transportation compartments still have to be developed (RIVM 2016, 2018).

The first release of GDOs into the environment presents a particular challenge for risk assessors and risk managers, because of the lacking experience and comparability with previous releases. Any deliberate release of a GDO for field-testing needs to consider that a single release of GDOs into the environment may have the potential for unlimited and global spread into wild populations. EFSA already recognizes the difficulty of conducting field trials with GM insects due to the irretrievability of GM 
insects in certain cases (EFSA 2013). The potential irreversibility concerns not only the GDOs themselves but also their potential environmental effects, which remain, even if the GDOs have been removed or have disappeared from the environment after the release. In many cases, such field testing under realistic environmental conditions is considered to be crucial, e.g. for the determination of functionality and efficacy of the gene drive application in-situ, but also for the assessment of ecological parameters and effects on local, wild-type organisms. Without information gained from field trials, there is a lack of data regarding the potential impact on target organisms, the GDOs' dispersal and population dynamics, and their possible ecological impact in the receiving environment. This will hamper the determination of the efficacy of the gene drive approach, but also of probabilities regarding the occurrence of potential adverse effects on human health and the environment. However, such probabilities are needed in order to characterise the potential risks.

Self-limiting approaches of GDOs have been suggested in order to control and halt further spread of GDOs into the environment, such as locally fixed gene drives (Sudweeks et al. 2019) or precision drives (Esvelt et al. 2014) which exclusively target a specific subpopulation. Other approaches for confinement of gene drives during field tests have been suggested, such as choosing environments without non-target populations for first releases of the GDO, the use of multiple levels of molecular containment and the use of visible markers in GDOs (Oye et al. 2014; NAS 2016). Presumed "self-exhausting" gene drive approaches (i.e. local drives) and strategies for countering drive systems and restoring wild-type populations have also been proposed (Noble et al. 2017; Min et al. 2018). However, these are theoretical approaches and proof-ofconcept studies are still lacking. As long as functional confinement strategies, employable marker systems and methods for monitoring and the retrievability of GDOs are missing, the release of GDOs for testing purposes should be avoided.

\section{Challenge 5: Long-term risks at the population and ecosystem level cannot be as- sessed with current ERA methods}

One particularity of the European GMO regulation is the assessment of long-term, indirect and delayed effects, referring to effects on human health or the environment "... which may not be observed during the period of the release of the GMO, but become apparent as a direct or indirect effect either at a later stage or after termination of the release" (European Commission 2001). The regulatory provisions distinguish direct from indirect effects, delineating direct effects on human health or the environment from those occurring through a causal chain of events. Commission Directive (EU) 2018/350 specifically mentions long-term effects of GMO which result "... either from a delayed response by organisms or their progeny to long-term or chronic exposure to a GMO or from an extensive use of a GMO in time and space". Long-term effects should be assessed by desk-based studies, considering a) practical knowledge and empirical data from the previous releases, either field testing or commercial use; b) available data sets or literature and c) mathematical modelling (European Commission 2018a). For GM crops, 
the use of models has been proposed, in particular for effects that cannot be assessed experimentally or at field scale (EFSA 2010a; EFSA 2013).

Currently, there is no practical knowledge or empirical data from environmental releases of GM insects or GM animals in the EU. No GM animals have so far been notified; neither for placing on the market nor for field-testing. It has been argued that the ERA of GDOs can be informed by experience gained with the release of biological control organisms (Devos et al. 2019), because there are some similarities regarding the release of GDOs and biological control agents released to control pest species (NAS 2016). While this may be true for certain biological aspects (e.g. host-specificity, retrievability issues, spread out of the intended area), it has to be considered that biological control organisms are mostly non-native species released into an "unfamiliar" environment which often leads to unpredictable outcomes (Louda et al. 2003). In contrast, gene drive applications aim to control native species in their "original" environment or non-native species that have already been present for some time in the new environment. In addition, long-term evaluations of biological control organisms are largely lacking, also due to the time delays between their introduction and the occurrence of harmful effects (EFSA 2013). Hence, any predictions of large-scale and long-term ecosystem effects of GDOs should not be based on the experiences with biological control organisms alone and consider the unique features of GDOs.

Literature of impacts of GDOs is currently limited to theoretical modelling exercises regarding the spread and functionality of specific gene drive constructs (see e.g. Marshall and Hay 2012; Akbari et al. 2013; Noble et al. 2017, 2018). In addition, there is a range of literature available that evaluates the pros and cons of different gene drive applications on a theoretical level (see e.g. Champer et al. 2016). Likewise, potential ecological implications have been discussed on a theoretical level only (e.g. David et al. 2013; Simon et al. 2018).

Experience with mathematical modelling for ERA purposes is available for GM crops such as $B t$ maize (e.g. EFSA 2012a, b). For risks of insecticidal $B t$ maize on nontarget Lepidoptera, a model has been developed to evaluate the exposure of lepidopteran larvae to the maize pollen on the butterflies' host plants (Perry et al. 2010; Perry et al. 2011, 2012). This model was then used for ERA purposes and the derivation of risk management strategies by EFSA (EFSA 2012a, b, 2015). However, the underlying assumptions of the model have been highly debated in the scientific literature (Holst et al. 2013; Kruse-Plass et al. 2017; Perry et al. 2017), which encouraged EFSA to re-evaluate the model (EFSA 2019). Although not used for ERA purposes, modelling studies have also been used to predict the persistence and dispersal of GM oilseed rape in agricultural landscapes, e.g. by quantitative extrapolation of effects through upscaling (Breckling et al. 2009; Middelhoff et al. 2011; Reuter et al. 2011). Modelling has also been used to assess agricultural risks of co-existence of GM and non-GM crops, e.g. due to cross contamination (e.g. Colbach et al. 2001a, b; Angevin et al. 2008; Colbach et al. 2008). For GDOs, mathematical models were used so far to address the spread of the cargo genes in the target population and the occurrence of resistant alleles (e.g. Unckless et al. 2015; Eckhoff et al. 2016; Noble et al. 2018). 
The controversies around the ERA in general and the model used in the ERA of $B t$ maize in particular have not ceased yet, even though many GM crops have been risk assessed over the years and, thus, some experience with the cultivation of $B t$ maize in the $\mathrm{EU}$ and a good data basis for the model input parameters is available. In contrast, no data to assess long-term risks of GDOs are available and mathematical models still have to be developed in order to specifically address the ecological processes that may be affected if GDOs are to be released into the environment.

\section{Challenge 6: Improved environmental monitoring and risk management must be operational before deploying GDOs}

Considering that a high level of uncertainty has been attributed to the environmental and human health risks of GDOs, the application of appropriate risk management strategies is of paramount importance. Risk management strategies should control the identified risk, cover the uncertainties and need to be available and functional at the time of first release. When cultivating GM crops, risk management involves the establishment of an insect resistance management plan, e.g. for insect resistant $B t$ maize, to minimize the risk of resistance development of the targeted pest species (EFSA 2012b). Also for GDOs, resistant phenotypes can compromise the functionality of the gene drive approach. Therefore molecular approaches have been suggested, which are presumed to undo genomic changes of a previous drive or occurring resistant phenotypes, e.g. by overwriting one or all previous genomic changes (i.e. "reversal" drive; Esvelt et al. 2014). This still theoretical approach aims to reverse the effect of GDOs and has been proposed as a kind of rescue of the original, wild-type sequence or phenotype (Min et al. 2018). All these proposals use the same technological approach as the original gene drive application. Therefore such "reversal drives" are also subject to the same regulatory requirements and evolutionary constraints as the originally deployed drive system. Even if the original molecular sequences will be re-established by the use of such drives, certain synthetic molecular elements will remain in the target population (e.g. coding for the nuclease or gRNA, Esvelt et al. 2014). Recently, certain molecular targets have been proposed with no observed selection of resistance alleles that impair the functionality of the drive (Kyrou et al. 2018). Although these "safe by design" approaches are in principle preferable, these are still conceptual and are currently far from being deployable.

In the EU, a post-release monitoring plan has to be submitted by the applicant of a GMO with the purpose (1) to validate the results of the ERA (i.e. case specific monitoring) and (2) to address any adverse effects which were not anticipated in the ERA, also referred to as general surveillance (European Commission 2001). In particular, general surveillance serves to detect indirect, delayed and/or long-term effects, thereby acting as an early warning system in order to rapidly implement or modify risk management measures and reduce consequences for the environment and human health. Due to the long-term and persistent character of gene drive applications in the environment, and the high level of uncertainty of adverse effects, monitoring must not only focus on the 
efficacy of the gene drive control strategy. Specifically, it needs to include monitoring of the occurrence and prevalence of the GDOs in those environmental compartments and habitats where these organisms are expected to occur. Monitoring has also been demanded in order to minimize risks for misuse of gene drive applications, e.g. by sequencing of populations and environments at risk if these contain genetic elements relevant for gene drive (Min et al. 2018). Long-term monitoring is particularly necessary if gene drive approaches are deployed as a public health tool, i.e. for control of disease-transmitting vectors, in order to guarantee long-term efficacy of the intervention. Thereby, adverse effects on human health due to the potential lack of functionality of the drive can be avoided. Monitoring approaches analogous to the pharmacovigilance of human medicinal products have also been demanded (WHO 2014). In addition, new data and information gained from monitoring can be used to inform the ERA, which should be regularly reviewed and updated, also with the aim to possibly adapt any risk management measures that have been applied (EAA 2011).

For insect-resistant GM crops, resistance monitoring has been shown to be effective in areas of cultivation of $B t$ maize (Camargo et al. 2018). In contrast, post-market environmental monitoring carried out for "classic" GM crops in the EU is not functional with respect to its objectives, design, data analysis, and selection of monitoring networks as well as the lack of a standardised methodology (EAA 2011). In addition, a comprehensive monitoring of the presence of GMOs in the environment has also been demanded for "classic" GMOs, but is currently not realised EU-wide (EAA 2011, Bühler et al. 2018). Due to these shortcomings of post-release environmental monitoring of GM crops in the EU, the monitoring aims, designs, methodologies and involved networks need to be adapted accordingly to address the specificities of gene drive applications before release into EU environments.

\section{Conclusions}

The use of genetically modified organisms with the ability for gene drive has been proposed to combat some of the most pressing human health, agronomic or environmental problems. Due to the potentially unlimited spread, both spatially and in time, gene drive applications may have severe consequences for target as well as nontarget populations, but also entire ecosystems or public health. Therefore, a cautious handling of these organisms is strongly suggested; the assessment of environmental risks, provisions for post-release monitoring and risk management measures should be standard requirements before release of GDOs into the environment. In order to achieve this, the regulatory oversight of GMOs in the EU has to be scrutinised to evaluate whether it is fit for purpose to cover the novel risks and challenges posed by gene drive applications.

Regulating GDOs according to the provisions of Directive 2001/18/EC for the deliberate release into the environment of GMOs provides the advantage that each environmental release requires a specific authorization, a preceding environmental 
risk assessment, including a phased release into the environment and a mandatory post-release environmental (and possibly human health) monitoring. This regulatory framework provides an EU-wide harmonised and robust approach in which potential adverse effects of gene drives to human health and the environment have to be determined, their likelihood assessed, the risks managed and monitored. The current regulatory provisions for GMOs in the EU are aligned to single-generation GMOs with no intentional spread or persistence in the environment; hence, consent for use is given for a maximum period of 10 years with the possibility for renewal. Any GDO to be released into the environment would have to comply with these regulatory requirements. From a regulatory view, it will be difficult to handle GDOs designed to disperse in the environment beyond a specific time frame, in particular if retrievability of these organisms is not readily available.

With the emergence and increased application of new genetic engineering techniques used inter alia for the construction of GDOs, an efficient risk assessment will have to address specific risk aspects for a range of different organisms at different taxonomic hierarchies. The major differences of gene drive approaches to conventional GM approaches refer to the targeting of wild populations and the intentional spread of synthetic genetic elements or novel traits throughout target populations and entire ecosystems with the potential for long-term adverse effects. These specificities have major implications for the ERA, with respect to the definition of the receiving environment, for the use of the comparative approach, the assessment of environmental harm due to gene flow and the testing of the organisms in the field, the assessment of long-term risks as well as for monitoring and risk management.

Specifically, long-term effects on whole populations or ecosystems including potential evolutionary changes in target and non-target populations are highly unpredictable and difficult to model. They pose a specific challenge for the risk assessment of GDOs. Uncertainties in the assessment of the likelihood of the occurrence and of the consequences of such long-term effects may result in highly speculative risk estimations. A comprehensive empirical data basis, new and systematic scientific approaches and improved predictive modelling of long-term effects at ecosystem level will be indispensable to evaluate such risks. In addition, a scientifically sound ERA needs a spatial and temporal reference framework for any GMO, which implies that ERA is not possible for globally spreading GDOs. This also implies that decisions on acceptable risks can only be made if enough data are available to assess the specific risk and if clear decision criteria are available regarding the acceptability of such risks, both for ERA and for monitoring. Last but not least, more emphasis than for "classic" GMOs needs to be put on post-release monitoring and the availability of risk management measures in order to enable timely detection of adverse effects on the environment and the possibility to halt or even reverse the spread of GDOs in the receiving environment. The decision of first release into the environment of a GDO, e.g. during field-testing, will not be easily tackled. The trade-off between gaining necessary information on efficacy and biosafety of the specific application in the receiving environment and the assessment of risks, based solely on data from confined environments, will have to be solved 
already at the beginning of the ERA. The final decision to release GDOs into the environment will, however, not be a purely scientific question, but will need some form of broader stakeholder engagement and the commitment to specific protection goals for human health and the environment.

\section{Acknowledgements}

We would like to thank Nina Gammenthaler (Swiss Federal Office for the Environment) for her valuable comments on the manuscript. The additional funding for this project provided by the Swiss Federal Office for the Environment (FOEN) is kindly acknowledged.

\section{References}

AAS (2017) Synthetic gene drives in Australia: Implications of emerging technologies. Australian Academy of Sciences. Canberra, Australia. https://www.science.org.au/support/analysis/reports/synthetic-gene-drives-australia-implications-emerging-technologies

Aebi A, Schoenenberger N (2016) Gene transfers into the environment. A report mandated by the Federal Ethics Committee on Non-Human Biotechnology. University of Neuchatel and Innovabridge, Switzerland. https://www.ekah.admin.ch

Akbari OS, Matzen KD, Marshall JM, Huang H, Ward CM, Hay BA (2013) A synthetic gene drive system for local, reversible modification and suppression of insect populations. Current Biology 23(8): 1-7. https://doi.org/10.1016/j.cub.2013.02.059

Akbari OS, Chen C-H, Marshall JM, Huang H, Antoshechkin I, Hay BA (2014) Novel synthetic Medea selfish genetic elements drive population replacement in Drosophila; a theoretical exploration of Medea-dependent population suppression. ACS Synthetic Biology 3(12): 915-928. ttps://doi.org/10.1021/sb300079h

Akbari OS, Bellen HJ, Bier E, Bullock SL, Burt A, Church GM, Cook KR, Duchek P, Edwards OR, Esvelt KM, Gantz VM, Golic KG, Gratz SJ, Harrison MM, Hayes KR, James AA, Kaufman TC, Knoblich J, Malik HS, Matthews K, O’Connor-Giles KM, Parks AL, Perrimon N, Port F, Russell S, Ueda R, Wildonger J (2015) Safeguarding gene drive experiments in the laboratory. Science 349(6251): 927-929. https://doi.org/10.1126/science.aac7932

Angevin F, Klein EK, Choimet C, Gauffreteau A, Lavigne C, Messean A, Meynard JM (2008) Modelling impacts of cropping systems and climate on maize cross-pollination in agricultural landscapes: The MAPOD model. European Journal of Agronomy 28(3): 471-484. https://doi.org/10.1016/j.eja.2007.11.010

Benedict M, Eckerstorfer MFG, Gaugitsch HG, Heissenberger A, Knols B, Kumschick S, Nentwig W, Rabitsch W (2010) Defining Environmental Risk Assessment Criteria for Genetically Modified Insects to be Placed on the EU Market. Scientific/Technical Report submitted to EFSA, 200 pp. https://doi.org/10.2903/sp.efsa.2010.EN-71

Besansky NJ, Lehmann T, Fahey GT, Fontenille D, Braack LEO, Hawley WA, Collins FH (1997) Patterns of mitochondrial variation within and between African Malaria vectors, 
Anopheles gambiae and A. ambiensis, suggest extensive gene flow. Genetics 147 (1817): 1817-1828. https://www.ncbi.nlm.nih.gov/pmc/articles/PMC1208348/

Bethenod MT, Thomas Y, Rousset F, Frérot B, Pélozuelo L, Genestier G, Bourguet D (2005) Genetic isolation between two sympatric host plant races of the European corn borer, Ostrinia nubilalis Hübner. II: Assortative mating and host-plant preferences for oviposition. Heredity 94(2): 264-270. https://doi.org/10.1038/sj.hdy.6800611

Bigler F, Bale JS, Cock MJW, Dreyer H, Greatrex R, Kuhlmann U, Loomans AJM, van Lenteren JC (2005) Guidelines on information requirements for import and release of invertebrate biological control agents in European countries. Biocontrol News and Information 26(4): 115N-123N. https://doi.org/10.1079/PAVSNNR20051001

Blackburn TM, Essl F, Evans T, Hulme PE, Jeschke JM, Kühn I, Kumschick S, Markova Z, Mrugała A, Nentwig W, Pergl J, Pyšek P, Rabitsch W, Ricciardi A, Richardson DM, Sendek A, Vilà M, Wilson JRU, Winter M, Genovesi P, Bacher S (2014) A Unified Classification of Alien Species Based on the Magnitude of their Environmental Impacts. PLoS Biology 12(5): e1001850. https://doi.org/10.1371/journal.pbio.1001850

Bourguet D, Bethenod MT, Trouve C, Viard F (2000) Host-plant diversity of the European corn borer Ostrinia nubilalis: What value for sustainable transgenic insecticidal $B t$ maize? Proceedings. Biological Sciences 2000(267): 1177-1184. https://doi.org/10.1098/ rspb.2000.1126

Bowman DT, May OL, Creech JB (2003) Genetic Uniformity of the U.S. Upland Cotton Crop since the Introduction of Transgenic Cottons. Crop Science 43(2): 515-518. https:// doi.org/10.2135/cropsci2003.0515

Breckling B, Reuter H, Middelhoff U, Glemnitz M, Wurbs A, Schmidt G, Schröder W, Windhorst W (2009) Risk indication of genetically modified organisms (GMO): Modelling environmental exposure and dispersal across different scales. Oilseed rape in Nothern Germany as an integrated case study. Ecological Indicators 11(4): 936-941. https://doi. org/10.1016/j.ecolind.2009.03.002

Bühler C, Kohli L, Rothet T (2018) Undesirable populations of genetically modified plant species in the environment. Recommendations for the design of a monitoring programme. Report commissioned by the Swiss Federal Office for the Environment FOEN.

Bull JJ (2015) Evolutionary decay and the prospects for long-term disease intervention using engineered insect vectors. Evolution, Medicine, and Public Health 2015(1): 152-166. https://doi.org/10.1093/emph/eov013

Bull JJ (2017) Lethal gene drive selects inbreeding. Evolution, Medicine, and Public Health 2017(1): 1-16. https://doi.org/10.1093/emph/eow030

Burt A (2003) Site-specific selfish genes as tools for the control and genetic engineering of natural populations. Proceedings. Biological Sciences 270(1518): 921-928. https://doi. org/10.1098/rspb.2002.2319

Burt A, Crisanti A (2018) Gene Drive: Evolved and Synthetic. ACS Chemical Biology 13(2): 343-346. https://doi.org/10.1021/acschembio.7b01031

Callaway E (2017a) Gene drives meet the resistance. Nature 542: 15. https:/doi. org/10.1038/542015a

Callaway E (2017b) US agencies tackle gene drives. Nature 547(7664): 388-389. https://doi. org/10.1038/nature.2017.22345 
Camargo AM, Andow DA, Castanera P, Farinos GP (2018) First detection of a Sesamia nonagrioides resistance allele to Bt maize in Europe. Scientific Reports 8(1): 1-3977. https://doi. org/10.1038/s41598-018-21943-4

Champer J, Buchman A, Akbari OS (2016) Cheating evolution: Engineering gene drives to manipulate the fate of wild populations. Nature Reviews. Genetics 17(3): 146-159. https://doi.org/10.1038/nrg.2015.34

Champer J, Reeves R, Oh SY, Liu C, Liu J, Clark AG, Messer PW (2017) Novel CRISPR/ Cas9 gene drive constructs reveal insights into mechanisms of resistance allele formation and drive efficiency in genetically diverse populations. PLOS Genetics 13(7): e1006796. https://doi.org/10.1371/journal.pgen.1006796

Champer J, Liu J, Oh SY, Reeves R, Luthra A, Oakes N, Clark AG, Messer PW (2018) Reducing resistance allele formation in CRISPR gene drive. Proceedings of the National Academy of Sciences of the United States of America 115(21): 5522-5527. https://doi. org/10.1073/pnas.1720354115

Civil Society Working Group on Gene Drives (2016) The case for a global moratorium on genetically-engineered gene drives. http://www.synbiowatch.org/gene-drives

Colbach N, Clermont-Dauphin C, Meynard JM (2001a) GeneSys: A model of the influence of cropping systems on gene escape from herbicide tolerant rapeseed crops to rape volunteers: I. Temporal evolution of a population of rapeseed volunteers in a field. Agriculture, Ecosystems \& Environment 83(3): 235-253. https://doi.org/10.1016/S0167-8809(00)00174-2

Colbach N, Clermont-Dauphin C, Meynard JM (2001b) GeneSys: a model of the influence of cropping system on gene escape from herbicide tolerant rapeseed crops to rape volunteers: II. Genetic exchanges among volunteer and cropped populations in a small region. Agriculture, Ecosystems \& Environment 83(3): 255-270. https://doi.org/10.1016/S01678809(00)00175-4

Colbach N, Dürr C, Gruber S, Pekrun C (2008) Modelling the seed bank evolution and emergence of oilseed rape volunteers for managing co-existence of GM and non-GM varieties. European Journal of Agronomy 28(1): 19-32. https://doi.org/10.1016/j.eja.2007.04.005

Constable A, Jonas D, Cockburn A, Davi A, Edwards G, Hepburn P, Herouet-Guicheney C, Knowles M, Moseley B, Oberdörfer R, Samuels F (2007) History of safe use as applied to the safety assessment of novel foods and foods derived from genetically modified organisms. Food and Chemical Toxicology 45(12): 2513-2525. https://doi.org/10.1016/j. fct.2007.05.028

CSS, ENSSER, VDW (2019) Gene Drives - A report on their science, applications, social aspects, ethics and regulations. Critical Scientists Switzerland (CSS), European Network of Scientists for Social and Environmental Responsibility (ENSSER) and Vereinigung Deutscher Wissenschaftler (VDW). https://genedrives.ch/report

David AS, Kaser JM, Morey AC, Roth AM, Andow DA (2013) Release of genetically engineered insects: A framework to identify potential ecological effects. Ecology and Evolution 3(11): 4000-4015. https://doi.org/10.1002/ece3.737

De Barro P, Murphy B, Jansen C, Murray J (2011) The proposed release of the yellow fever mosquito Aedes aegypti containing a naturally occurring strain of Wolbachia pipientis, a question of regulatory responsibility. Journal für Verbraucherschutz und Lebensmittelsicherheit 6(Suppl 1): 33-40. https://doi.org/10.1007/s00003-011-0671-x 
de Jong TJ (2017) Gene drives do not always increase in frequency: from genetic models to risk assessment. Journal for Consumer Protection and Food Safety. https://doi.org/10.1007/ s00003-017-1131-z

Deredec A, Godfray HCJ, Burt A (2011) Requirements for effective malaria control with homing endonuclease genes. Proceedings of the National Academy of Sciences of the United States of America 108(43): E874-E880. https://doi.org/10.1073/pnas.1110717108

Devlin RH, D'Andrade M, Uh M, Biagi CA (2004) Population effects of growth hormone transgenic Coho salmon depend on food availability and genotype by environment interactions. Proceedings of the National Academy of Sciences of the United States of America 101(25): 9303-9308. https://doi.org/10.1073/pnas.0400023101

Devos Y, Craig W, Devlin RH, Ippolito A, Leggatt RA, Romeis J, Shaw R, Svendsen C, Topping CJ (2019) Using problem formulation for fit-for-purpose pre-market environmental risk assessments of regulated stressors. EFSA Journal 17(S1): e170708. https://doi. org/10.2903/j.efsa.2019.e170708

DiCarlo JE, Chavez A, Dietz SL, Esvelt KM, Church GM (2015a) Safeguarding CRISPR-Cas9 gene drives in yeast. Nature Biotechnology 33(12): 1250-1255. https://doi.org/10.1038/ nbt. 3412

DiCarlo JE, Chavez A, Dietz SL, Esvelt KM, Church GM (2015b) RNA-guided gene drives can efficiently bias inheritance in wild yeast. [bioRxiv preprint first posted online Jan. 16, 2015] https://doi.org/10.1101/013896

EAA (2011) Monitoring of genetically modified organisms. A joint policy paper by BfN (Germany), FOEN (Switzerland) and EAA (Austria). Environment Agency Austria, Vienna, Report REP-0305. http://www.umweltbundesamt.at

Eckerstorfer MF, Dolezel M, Heissenberger A, Miklau M, Reichenbecher W, Steinbrecher RA, Waßmann F (2019) An EU perspective on biosafety considerations for plants developed by genome editing and other new genetic modification techniques (nGMs). Frontiers in Bioengineering and Biotechnology 7: 1-31. https://doi.org/10.3389/fbioe.2019.00031

Eckhoff PA, Wenger EA, Godfray HCJ, Burt A (2016) Impact of mosquito gene drive on malaria elimination in a computational model with explicit spatial and temporal dynamics. Proceedings of the National Academy of Sciences of the United States of America 114(2): E255-E264. https://doi.org/10.1073/pnas.1611064114

EFSA (2010a) Guidance on the environmental risk assessment of genetically modified plants. EFSA Journal 8(11): 1-1879. https://doi.org/10.2903/j.efsa.2010.1879

EFSA (2010b) Scientific Opinion on the assessment of potential impacts of genetically modified plants on non-target organisms. EFSA Journal 8(11): 1-1877. https://doi.org/10.2903/j. efsa.2010.1877

EFSA (2011) Scientific Opinion on application (EFSA-GMO-CZ-2008-54) for placing on the market of genetically modified insect resistant and herbicide tolerant maize MON 88017 for cultivation under Regulation (EC) No 1829/2003 from Monsanto. EFSA Journal 9(11): 1-2428. https://doi.org/10.2903/j.efsa.2011.2428

EFSA (2012a) Scientific Opinion supplementing the conclusions of the environmental risk assessment and risk management recommendations for the cultivation of the genetically modified insect resistant maize 1507 for cultivation. EFSA Journal 10(11): 1-2934. https://doi.org/10.2903/j.efsa.2012.2934 
EFSA (2012b) Scientific Opinion supplementing the conclusions of the environmental risk assessment and risk management recommendations for the cultivation of the genetically modified insect resistant maize Bt11 and MON810. EFSA Journal 10(12): 1-3016. https://doi.org/10.2903/j.efsa.2012.3016

EFSA (2013) Guidance on the environmental risk assessment of genetically modified animals. EFSA Journal 11(5): 1-3200. https://doi.org/10.2903/j.efsa.2013.3200

EFSA (2015) Updating risk management recommendations to limit exposure of non-target Lepidoptera of conservation concern in protected habitats to Bt-maize pollen. EFSA Journal 13(7): 1-4127. https://doi.org/10.2903/j.efsa.2015.4127

EFSA (2019) Non-target Lepidoptera procurement. Presentation at the $10^{\text {th }}$ Scientific Network on Risk Assessment of GMOs, $18^{\text {th }}$ June 2019, Parma. https://www.efsa.europa.eu/en/ events/event/190618

Ellstrand NC (2003) Current knowledge of gene flow in plants: Implications for transgene flow. Philosophical Transactions of the Royal Society of London. Series B, Biological Sciences 358(1434): 1163-1170. https://doi.org/10.1098/rstb.2003.1299

Ellstrand NC, Meirmans P, Rong J, Bartsch D, Gosh A, de Jong TJ, Haccou P, Lu BR, Snow AA, Steward Jr CN, Strasburg JL, van Tienderen PH, Vrieling K, Hooftmann D (2013) Introgression of crop alleles into wild or weedy populations. Annual Review of Ecology Evolution and Systematics 44(1): 325-345. https://doi.org/10.1146/annurev-ecolsys-110512-135840

Esvelt KM, Smidler AL, Catteruccia F, Church GM (2014) Concerning RNA-guided gene drives for the alteration of wild populations. eLife. https://doi.org/10.7554/eLife.03401

Esvelt KM (2017) Precaution: Open gene drive research. Nature 355(6325): 589-590. https:// doi.org/10.1126/science.aal5325

European Commission (2017) New Techniques in Agricultural Biotechnology. Explanatory Note 02. Directorate-General for Research and Innovation, Scientific Advice Mechanism (SAM). https://ec.europa.eu/research/sam/index.cfm?pg=agribiotechnology

European Commission (2001) Directive 2001/18/EC of the European Parliament and of the Council of 12 March 2001 on the deliberate release into the environment of genetically modified organisms and repealing Council Directive 90/220/EEC - Commission Declaration. OJL 106: 1-39. https://eur-lex.europa.eu/legal-content/EN/ TXT/?uri=CELEX\%3A32001L0018

European Commission (2018a) Commission Directive (EU) 2018/350 of 8 March 2018 amending Directive 2001/18/EC of the European Parliament and of the Council as regards the environmental risk assessment of genetically modified organisms. OJL 67: 3045. https://eur-lex.europa.eu/legal-content/GA/TXT/?uri=CELEX:32018L0350

European Commission (2018b) Commission Implementing Decision (EU) 2018/1790 of 16 November 2018 repealing Decision 2002/623/EC establishing guidance notes on the environmental risk assessment of genetically modified organisms (notified under document C(2018) 7513). OJL 293: 32-33. https://eur-lex.europa.eu/legal-content/EN/ TXT/?uri=CELEX\%3A32018D1790

Gantz VM, Bier E (2015) The mutagenic chain reaction: A method for converting heterozygous to homozygous mutations. Science 348(6233): 442-444. https://doi.org/10.1126/ science.aaa 5945 
Gantz VM, Jasinskiene N, Tatarenkova O, Fazekas A, Macias VM, Bier E, James AA (2015) Highly efficient Cas9-mediated gene drive for population modification of the malaria vector mosquito Anopheles stephensi. Proceedings of the National Academy of Sciences. https://doi.org/10.1073/pnas.1521077112

Gimonneau G, Bouyer J, Morand S, Besansky NJ, Diabate A, Simard F (2010) A behavioral mechanism underlying ecological divergence in the malaria mosquito Anopheles gambiae. Behavioral Ecology 21(5): 1087-1092. https://doi.org/10.1093/beheco/arq114

Grunwald HA, Gantz VM, Poplawski G, Xu XS, Bier E, Cooper KL (2019) Super-Mendelian inheritance mediated by CRISPR/Cas9 in the female mouse germline. Nature 566(7742): 105-109. https://doi.org/10.1038/s41586-019-0875-2

Hammond AM, Galizi R (2018) Gene drives to fight malaria: Current state and future directions. Pathogens and Global Health. https://doi.org/10.1080/20477724.2018.1438880

Hammond A, Galizi R, Kyrou K, Simoni A, Siniscalchi C, Katsanos D, Gribble M, Baker D, Marois E, Russell S, Burt A, Windbichler N, Crisanti A, Nolan T (2016) A CRISPR-Cas9 gene drive system targeting female reproduction in the malaria mosquito vector Anopheles gambiae. Nature Biotechnology 34(1): 78-83. https://doi.org/10.1038/nbt.3439

Hammond A, Kyrou K, Bruttini M, North A, Galizi R, Karlsson X, Carpi FM, D’Aurizio R, Crisanti A, Nolan T (2017) The creation and selection of mutations resistant to a gene drive over multiple generations in the malaria mosquito. PLOS Genetics 13(10): e1007039. https://doi.org/10.1371/journal.pgen.1007039

Hartley S, Thizy DC, Ledingham K, Coulibaly M, Diabate A, Dicko B, Diop S, Kayondo J, Namukwaya A, Nourou B, Paré Toé L (2019) Knowledge engagement in gene drive research for malaria control. PLoS Neglected Tropical Diseases 13(4): e0007233. https://doi. org/10.1371/journal.pntd.0007233

Hayes KR, Hosack GR, Dana GV, Foster SD, Ford JH, Thresher R, Ickowicz A, Peel D, Tizard M, De Barro P, Strive T, Dambacher JM (2018) Identifying and detecting potentially adverse ecological outcomes associated with the release of gene-drive modified organisms. Journal of Responsible Innovation 5(sup1): S139-S158. https://doi.org/10.1080/232994 60.2017.1415585

Hoffmann AA, Montgomery BL, Popovici J, Iturbe-Ormaetxe I, Johnson PH, Muzzi F, Greenfield M, Durkan M, Leong YS, Dong Y, Cook H, Axford J, Callahan AG, Kenny N, Omodei C, McGraw EA, Ryan PA, Ritchie SA, Turelli M, O’Neill SL (2011) Successful establishment of Wolbachia in Aedes populations to suppress dengue transmission. Nature 476(7361): 454-457. https://doi.org/10.1038/nature10356

Holst N, Lang A, Lövei G, Otto M (2013) Increased mortality is predicted of Inachis io larvae caused by Bt-maize pollen in European farmland. Ecological Modelling 250: 126-133. https://doi.org/10.1016/j.ecolmodel.2012.11.006

Hunt EJ, Kuhlmann U, Sheppard A, Qin TK, Barratt BIP, Harrison L, Mason PG, Parker D, Flanders RV, Goolsby J (2007) Review of invertebrate biological control agent regulation in Australia, New Zealand, Canada and the USA: Recommendations for a harmonized European system. Journal of Applied Entomology. https://doi.org/10.1111/j.1439-0418.2007.01232.x Iturbe-Ormaetxe I, Walker T, O'Neill SL (2011) Wolbachia and the biological control of mosquito-borne disease. EMBO Reports 12(6): 508-518. https://doi.org/10.1038/embor. 2011.84 
Kofler N, Collins JP, Kuzma J, Marris E, Esvelt K, Nelson MP, Newhouse A, Rothschild LJ, Vigliotti VS, Semenov M, Jacobsen R, Dahlman JE, Prince S, Caccone A, Brown T, Schmitz OJ (2018) Editing nature: Local roots of global governance. Science 362(6414): 527-529. https://doi.org/10.1126/science.aat4612

Kruse-Plass M, Hofmann F, Kuhn U, Otto M, Schlechtriemen U, Schröder B, Voegel R, Wosniok W (2017) Reply to the EFSA (2016) on the relevance of recent publications (Hofmann et al. 2014, 2016) on environmental risk assessment and management of Bt-maize events (MON810, Bt11 and 1507). Environmental Sciences Europe 29(1): 1-12. https:// doi.org/10.1186/s12302-017-0106-0

Kuzma J (2019) Procedurally robust risk assessment framework for novel genetically engineered organisms and gene drives. Regulation \& Governance: 1-22. https://doi.org/10.1111/ rego. 12245

Kyrou K, Hammond AM, Galizi R, Kranjc N, Burt A, Beaghton AK, Nolan T, Crisanti A (2018) A CRIS PR-Cas9 gene drive targeting doublesex causes complete population suppression in caged Anopheles gambiae mosquitoes. Nature Biotechnology 36(11): 10621066. https://doi.org/10.1038/nbt.4245

Leftwich PT, Edgington MP, Harvey-Samuel T, Carabajal Paladino LZ, Norman VC, Alphey L (2018) Recent advances in threshold-dependent gene drives for mosquitoes. Biochemical Society Transactions 46(5): 1203-1212. https://doi.org/10.1042/BST20180076

Lindholm AK, Dyer KA, Firman RC, Fishman L, Forstmeier W, Holman L, Johannesson H, Knief U, Kokko H, Larracuente AM, Manser A, Montchamp-Moreau C, Petrosyan VG, Pomiankowski A, Presgraves DC, Safronova LD, Sutter A, Unckless RL, Verspoor RL, Wedell N, Wilkinson GS, Price TAR (2016) The ecology and evolutionary dynamics of meiotic drive. Trends in Ecology \& Evolution 31(4): 315-326. https://doi.org/10.1016/j.tree.2016.02.001 Louda SM, Pemberton RW, Johnson MT, Follett PA (2003) Nontarget Effects-The Achilles' Heel of Biological Control? Retrospective Analyses to Reduce Risk Associated with Biocontrol Introductions. Annual Review of Entomology 48(1): 365-396. https://doi. org/10.1146/annurev.ento.48.060402.102800

Macias VM, Ohm JR, Rasgon JL (2017) Gene Drive for Mosquito Control: Where Did It Come from and Where Are We Headed? International Journal of Environmental Research and Public Health 14(9): 1-1006. https://doi.org/10.3390/ijerph14091006

Marshall JM, Akbari OS (2016) Gene Drive Strategies for Population Replacement. In: Adelman ZN (Ed.) Genetic Control of Malaria and Dengue. Elsevier, 169-200. https://doi. org/10.1016/B978-0-12-800246-9.00009-0

Marshall JM, Akbari OS (2018) Can CRISPR-based gene drive be confined in the wild? A question for molecular and population biology. ACS Chemical Biology 13(2): 424-430. https://doi.org/10.1021/acschembio.7b00923

Marshall J, Hay B (2012) Confinement of gene drive systems to local populations: A comparative analysis. Journal of Theoretical Biology 294: 153-171. https://doi.org/10.1016/j. jtbi.2011.10.032

Marshall JM, Buchman A, Sanchez CHM, Akbari OS (2017) Overcoming evolved resistance to population-suppressing homing-based gene drives. Scientific Reports 7(1): 1-3776. https://doi.org/10.1038/s41598-017-02744-7 
Martel C, Réjasse A, Rousset F, Bethenod MT, Bourguet D (2003) Host-plant associated genetic differentiation in Northern French populations of the European corn borer. Heredity 90(2): 141-149. https://doi.org/10.1038/sj.hdy.6800186

Medlock J, Luz PM, Struchiner CJ, Galvani AP (2009) The impact of transgenic mosquitoes on dengue virulence to humans and mosquitoes. American Naturalist 174(4): 565-577. https://doi.org/10.1086/605403

Meyer RS, Purugganan MD (2013) Evolution of crop species: Genetics of domestication and diversification. Nature Reviews. Genetics 14(12): 840-852. https://doi.org/10.1038/nrg3605

MiddelhoffU, Reuter H, Breckling B (2011) GeneTraMP, a spatio-temporal model of the dispersal and persistence of transgenes in feral, volunteer and crop plants of oilseed rape and related species. Ecological Indicators 11(4): 974-988. https://doi.org/10.1016/j.ecolind.2009.03.006

Miles A, Harding NJ, Bottà G, Clarkson CS, Antão T, Kozak K, Schrider DR, Kern AD, Redmond S, Sharakhov I, Pearson RD, Bergey C, Fontaine MC, Donnelly MJ, Lawniczak MKN, Kwiatkowski DP, Donnelly MJ, Ayala D, Besansky NJ, Burt A, Caputo B, Della Torre A, Fontaine MC, Godfray HCJ, Hahn MW, Kern AD, Kwiatkowski DP, Lawniczak MKN, Midega J, Neafsey DE, O'Loughlin S, Pinto J, Riehle MM, Sharakhov I, Vernick KD, Weetman D, Wilding CS, White BJ, Troco AD, Pinto J, Diabaté A, O'Loughlin S, Burt A, Costantini C, Rohatgi KR, Besansky NJ, Elissa N, Pinto J, Coulibaly B, Riehle MM, Vernick KD, Pinto J, Dinis J, Midega J, Mbogo C, Bejon P, Wilding CS, Weetman D, Mawejje HD, Donnelly MJ, Weetman D, Wilding CS, Donnelly MJ, Stalker J, Rockett K, Drury E, Mead D, Jeffreys A, Hubbart C, Rowlands K, Isaacs AT, Jyothi D, Malangone C, Vauterin P, Jeffery B, Wright I, Hart L, Kluczyński K, Cornelius V, MacInnis B, Henrichs C, Giacomantonio R, Kwiatkowski DP, Cornelius V, MacInnis B, Henrichs C, Giacomantonio R, Kwiatkowski DP (2017) Genetic diversity of the African malaria vector Anopheles gambiae. Nature 552(7683): 96-100. https://doi.org/10.1038/nature24995

Min J, Smidler AL, Najjar D, Esvelt KM (2018) Harnessing gene drive. Journal of Responsible Innovation 5(sup1): S40-S65. https://doi.org/10.1080/23299460.2017.1415586

Murphy B, Jansen C, Murray J, De Barro P (2010) Risk analysis on the Australian release of Aedes aegypti (L.) (Diptera: Culicidae) contining Wolbachia. http://www.cisro.au

NAS (2016) Gene Drives on the Horizon: Advancing Science, Navigating Uncertainty, and Aligning Research with Public Values. Washington DC. https://doi.org/10.17226/23405

Noble Ch, Olejarz J, Esvelt KM, Church GM, Nowak MA (2017) Evolutionary dynamics of CRISPR gene drives. Science Advances 3(4): e1601964. https://doi.org/10.1126/sciadv.1601964

Noble Ch, Adlam B, Church GM, Esvelt KM, Novak MA (2018) Current CRISPR gene drive systems are likely to be highly invasive in wild populations. eLife 7: e33423. https://doi. org/10.7554/eLife.33423

O’Brochta DA (2016) Genetic-control of mosquitoes. ISB News Report, February 2016. https://vtechworks.lib.vt.edu/bitstream/handle/10919/78870/ISB-News-Report-Feb16. pdf? sequence $=1$ \&isAllowed $=y$

Oliveira E, Salgueiro P, Palsson K, Vicente JL, Arez AP, Jaenson TG, Caccone A, Pinto J (2008) High levels of hybridization between molecular forms of Anopheles gambiae from Guinea Bissau. Journal of Medical Entomology 45(6): 1057-1063. https://doi.org/10.1093/jmedent/45.6.1057 
Oye KA, Esvelt K, Appleton E, Catteruccia F, Church GM, Kuiken T, Lightfoot SBY, McNamara J, Smidler AL, Collins JP (2014) Regulating gene drives. Sciencexpress. https://doi. org/10.1126/science.1254287

Perry JN, Devos Y, Arpaia S, Bartsch D, Gathmann A, Hails RS, Kiss J, Lheureux K, Manachini B, Mestdagh S, Neemann G, Ortego F, Schiemann J, Sweet JB (2010) A mathemati$\mathrm{cal}$ model of exposure of nontarget Lepidoptera to $\mathrm{Bt}$-maize pollen expressing Cry $\mathrm{Ab}$ within Europe. Proceedings of the Royal Society B 277(1686): 1417-1425. https://doi. org/10.1098/rspb.2009.2091

Perry JN, Devos Y, Arpaia S, Bartsch D, Gathmann A, Hails RS, Kiss J, Lheureux K, Manachini B, Mestdagh S, Neemann G, Ortego F, Schiemann J, Sweet JB (2011) The usefulness of a mathematical model of exposure for environmental risk assessment. Proceedings. Biological Sciences 278(1708): 982-984. https://doi.org/10.1098/rspb.2010.2667

Perry JN, Devos Y, Arpaia S, Bartsch D, Ehlert C, Gathmann A, Hails RS, Hendriksen NB, Kiss J, Messean A, Mestdagh S, Neemann G, Nuti M, Sweet JB, Tebbe CC (2012) Estimating the effects of Cry1F Bt-maize pollen on non-target Lepidoptera using a mathematical model of exposure. Journal of Applied Ecology 49(1): 29-37. https://doi.org/10.1111/ j.1365-2664.2011.02083.x

Perry JN, Barberi P, Bartsch D, Birch ANE, Gathmann A, Kiss J, Manachini B, Nuti M, Rauschen S, Schiemann J, Schuppener M, Sweet J, Tebbe C, Veronesi F (2017) Response to Kruse-Plass [et al.] (2017) regarding the risk to non-target lepidopteran larvae exposed to pollen from one or more of three Bt maize events (MON810, Bt11 and 1507). Environmental Sciences Europe 2017(29): 1-21. https://doi.org/10.1186/s12302-017-0119-8

Reuter H, Schmidt G, Schröder W, Middelhoff U, Pehlke H, Breckling B (2011) Regional distribution of genetically modified organisms (GMOs) - Up-scaling the dispersal and persistence potential of herbicide resistant oilseed rape (Brassica napus). Ecological Indicators 11(4): 989-999. https://doi.org/10.1016/j.ecolind.2009.03.007

RIVM (2016) Gene Drives. Policy Report. RIVM Letter report 2016-0023. National Institute for Public Health and the Environment. http://www.rivm.nl

RIVM (2018) Risk assessment method for activities involving organisms with a gene drive under contained use. RIVM Letter report 2018-0090. National Institute for Public Health and the Environment. doi: 10.21945/RIVM-2018-0090

Rode NO, Estoup A, Bourguet D, Courtier-Orogozo V, Débarre F (2019) Population management using gene drive: Molecular design, spread dynamics modelling and assessment of ecological risks. Conservation Genetics 20(4): 671-690. https://doi.org/10.1007/s10592-019-01165-5

Sander JD, Joung JK (2014) CRISPR-Cas systems for editing, regulating and targeting genomes. Nature Biotechnology 32(4): 347-355. https://doi.org/10.1038/nbt.2842

Santoiemma G, Trivellato F, Caloi V, Mori N, Marini L (2018) Habitat preference of Drosophila suzukii across heterogeneous landscapes. Journal of Pest Science. https://doi.org/10.1007/ s10340-018-1052-3

Simon S, Otto M, Engelhard M (2018) Synthetic gene drive: Between continuity and novelty. EMBO Reports 45760. https://doi.org/10.15252/embr.201845760

Singelton GR, Redhead TD (1990) Structure and biology of house mouse populations that plague irregularly: An evolutionary perspective. Biological Journal of the Linnean Society. Linnean Society of London 41(1-3): 285-300. https://doi.org/10.1111/j.1095-8312.1990.tb00837.x 
Sinkins SP, Gould F (2006) Gene drive systems for insect disease vectors. Nature Reviews. Genetics 7(6): 427-435. https://doi.org/10.1038/nrg1870

Sudweeks J, Hollingsworth B, Blondel DV, Campbell KJ, Dhole S, Eisemann JD, Edwards O, Godwin J, Howald GR, Oh KP, Piaggio AJ, Prowse TAA, Ross JV, Saah JR, Shiels AB, Thomas PQ, Threadgill DW, Vella MR, Gould F, Lloyd AL (2019) Locally Fixed Alleles: A method to localize gene drive to island populations. Scientific Reports 9(1): 1-15821. https://doi.org/10.1038/s41598-019-51994-0

Sundström LF, Löhmus M, Tymchuk WE, Devlin RH (2007) Gene-environment interactions influence ecological consequences of transgenic animals. Proceedings of the National Academy of Sciences of the United States of America 104(10): 3889-3894. https://doi. org/10.1073/pnas.0608767104

Target Malaria (2019) Target Malaria. https://targetmalaria.org/our-work/our-approach/ [accessed on June, 19 th, 2019$]$

Trtikova M, Wikmark OG, Zemp N, Widmer A, Hilbeck A (2015) Transgene Expression and $B t$ Protein Content in Transgenic Bt Maize (MON810) under Optimal and Stressful Environmental Conditions. PLoS ONE 10(4): e0123011. https://doi.org/10.1371/journal. pone.0123011

Unckless RL, Messer PW, Connallon T, Clark AG (2015) Modelling the manipulation of natural populations by the mutagenic chain reaction. Genetics 201(2): 425-431. https://doi. org/10.1534/genetics.115.177592

Vella MR, Gunning CE, Loyd AL, Gould F (2017) Evaluating strategies for reversing CRISPRCas9 gene drives. Scientific Reports 7(1): 1-11038. https://doi.org/10.1038/s41598-017$10633-2$

WHO (2014) The Guidance Framework for testing genetically modified mosquitoes. Programme for Research and Training in Tropical diseases. http://www.who.int

Xia H, Zhang H, Wang W, Yang X, Wang F, Su J, Xia H, Xu K, Cai X, Lu BR (2016) Ambient insect pressure and recipient genotypes determine fecundity of transgenic crop-weed rice hybrid progeny: Implications for environmental biosafety assessment. Evolutionary Applications 9(7): 847-856. https://doi.org/10.1111/eva.12369

Yang X, Li L, Jiang X, Wang W, Cai X, Su J, Wang F, Lu BR (2017) Genetically engineered rice endogenous 5-enolpyruvoylshikimate-3-phosphate synthase (epsps) transgene alters phenology and fitness of crop-wild hybrid offspring. Scientific Reports 7(1): 1-6834. https:// doi.org/10.1038/s41598-017-07089-9

Zeller SL, Kalinina O, Brunner S, Keller B, Schmid B (2010) Transgene x Environment Interactions in Genetically Modified Wheat. PLoS ONE 5(7): e11405. https://doi.org/10.1371/ journal.pone.0011405 